\title{
Effectiveness of Structured Teaching Programme on Knowledge Regarding Legal Aspects of Forensic Psychiatry among Staff Nurses at Selected Hospital, Coimbatore
}

\author{
Punithavalli. $\mathbf{P}^{1}$, Abirami ${ }^{2}$, Jebaseeli Gladies ${ }^{3}$, Bijilin Reeni. $\mathbf{D}^{4}$ \\ ${ }^{1}$ Nursing Tutor, E. S College of Nursing, Villupuram. \\ ${ }^{2}$ Prof. PPG College of Nursing, Coimbatore. \\ ${ }^{3}$ Associate Professor, E. S College of Nursing, Villupuram. \\ ${ }^{4}$ Assistant Professor, E. S College of Nursing, Villupuram. \\ Corresponding Author: Punithavalli. P
}

DOI: https://doi.org/10.52403/gijash.20220101

\begin{abstract}
Aim: To evaluate the effectiveness of Structured Teaching Programme on knowledge regarding Legal Aspects of Forensic Psychiatry among staff nurses at selected hospital, Coimbatore.

Objectives: (i) To assess the level knowledge regarding legal aspects in forensic psychiatry among staff nurses. (ii) To administer structured teaching programme regarding the legal aspects in forensic psychiatry among staff nurses. (iii) To evaluate the effectiveness of structured teaching programme on level of knowledge regarding legal aspects in forensic psychiatry among staff nurses. (iv) To find out the association between selected demographic variables with the post test knowledge score of staff nurses. Quasi experimental, non equivalent, one group pretest posttest design was adopted. A simple random sampling technique was used select 50 staff nurses. A Modified Structured Knowledge Questionnaire was used to assess the knowledge on Legal Aspects of Forensic Psychiatry. The modified conceptual frame work for the present study was based on Wiedenbach's Clinical Nursing Practice-A Helping Art Theory. The study was conducted at selected hospital in Coimbatore among 50 staff nurses and the data collected was analyzed and interpreted based on descriptive and inferential statistics. The pretest mean was 15.22 and post test mean was 20.82 there was significant difference between the
\end{abstract}

level of knowledge among the subjects in pretest and post test after implementation of STP $(\mathrm{t}=11.61$ and $\mathrm{p}<=0.05)$. The study shows that the STP on legal aspects in forensic psychiatry was effective in improving the knowledge of staff nurses.

Key Words: Structured Teaching Programme, Legal Aspects, Forensic Psychiatry

\section{INTRODUCTION}

Psychiatric nursing is the science and art of providing protective, therapeutic, supportive, physical and social care to the people too ill to be completely responsible for management for their own behavior. For clients in mental hospitals and other institutional settings, the psychiatric nurse is the primary health care provider and is in fact, a primary mental health care nurse.

The term "forensic" is derived from the word "forum" referring to the roman market place where lawyers once met to debate. Today most people would associate the word forensic with dead bodies and investigation of death as a sequel to criminal activity.

Forensic psychiatry is the branch of medicine that deals with disorders of the mind and their relation to legal principles. Forensic psychiatry continues to be concerned primarily with mentally 
disordered offenders but now encompasses a wide range of offences and gives much more prominence to diagnosis, management and treatment, in prison, hospital or the community, using the skills of various mental health professionals.

The scope of forensic psychiatry can be broadly defined as those areas where psychiatry interacts with the law. Although all psychiatrists may be involved from time to time in forensic work, forensic psychiatrists are specifically involved in the assessment and management of mentally disordered offenders and other patients with mental disorders who are or have been potentially or actually, violent. Provision of forensic services varies across the country and forensic psychiatrists work in a variety of settings. E.g.: high security hospitals; medium secure units; low- secure wards and sometimes open wards; outpatient; day hospitals; and within community teams; prisons. The forensic psychiatry mentally disordered offenders; legal and ethical issues including mental health legislation and other non - criminal legal matters.

The title of forensic nursing is unfamiliar to many nurses. This is not surprising as the recognition of nursing practice as "forensic" in nature is not wide spread throughout whole world.

The essential duty of care is to meet patient's needs, while developing a degree of critical awareness, to recognize and process evidence where it exists. Several issues and challenges have been identified impacting on forensic nursing: a lack of awareness on legal and ethical issues, mental health act, legislation etc related to forensic psychiatry among nurses that they actually offer forensic care and pertinent ethical dilemmas; physical and verbal abuse; stress and burnout and decreased job satisfaction etc.

\section{OBJECTIVES:}

1. To assess the level knowledge regarding legal aspects in forensic psychiatry among staff nurses.
2. To administer structured teaching programme regarding the legal aspects in forensic psychiatry among staff nurses.

3. To evaluate the effectiveness of structured teaching programme on level of knowledge regarding legal aspects in forensic psychiatry among staff nurses.

4. To find out the association between selected demographic variables with the posttest knowledge score of staff nurses.

\section{HYPOTHESIS:}

There is a significant difference between pretest and post test scores of knowledge regarding forensic psychiatry among staff nurses

\section{METHODOLOGY}

The purpose of the study was to evaluate the effectiveness of STP on knowledge regarding Legal Aspects of Forensic Psychiatry among staff nurses at selected hospital, Coimbatore.

A Quasi experimental-one group pretest posttest design was carried out in this study. In this study simple random sampling technique was used to select 50 staff nurses for both experimental and control group. The pre test and post test level of knowledge was assessed using a modified Knowledge Questionnaire.

\section{LITERATURE REVIEW}

Burdekin (2015), The study conducted on Medical Ethics, Duties \& Medical Negligence Awareness among the Practitioners in a Teaching Medical College, Hospital. The study aimed to assess the knowledge of, and attitudes to, medical ethics among doctors in the Kalinga Institute of Medical Sciences (KIMS), Bhubaneswar, Orissa. Totally 120 numbers of practitioners of various clinical departments participated. Descriptive design was used. The study results show that $90 \%$ of the total participants were well aware about medico legal cases. All the participants advocated for an ethical 
practice but $12 \%$ of them practice as per the demand of the situation. $68 \%$ of the participants expressed that dichotomy.

Kondurureddemma (2015) The study was conducted on "Psychiatric nursing care in Brazil: Legal and Ethical aspects" in Ribeirao Preto College of Nursing, Brazil. In this study Human rights, considered as rights inherent to all human beings, must be respected unconditionally, especially during health care delivery. These rights became actually protected by International Law when the UN was created in 1945 In their practice, nurses attempt to conciliate patients' rights with their legal role and concerns with high-quality psychiatric care. In coping with these dilemmas, these professionals are active in three spheres: as health care providers, as employees of a health organization and as citizens.

SNCW; Hallberg et.al. (2015) A comparative study was conducted on burnout and job satisfaction among psychiatric nurses from forensic and mainstream mental health service in the Melbourne. The overall aim of this study is to measure the effectiveness of clinical supervision in reducing stress and burnout among nurses. The study adopted a survey design to compare forensic psychiatric nurses $(n=51)$ with psychiatric nurses from a mainstreamed mental health service $(n=$ 78) in relation to burnout and job satisfaction. The overall result of this study reveals that forensic nurses displayed lower burnout and higher job satisfaction than their counterparts from the mainstreamed services. These findings are surprising in light of the image of forensic psychiatric nursing as dangerous and unpredictable.

\section{RESULT AND DISCUSSION}

Assessment of pre and post-test level of knowledge regarding Legal Aspects of Forensic Psychiatry among staff nurses in experimental and control group.

Table 4.2.1: Distribution of level of knowledge among staff nurses about legal aspects in forensic psychiatry. $\mathrm{N}=50$

\begin{tabular}{|c|l|c|c|c|c|}
\hline $\begin{array}{l}\text { S.N } \\
\text { o }\end{array}$ & $\begin{array}{l}\text { Level Of } \\
\text { Knowledge }\end{array}$ & \multicolumn{2}{|l|}{ Pre-Test } & \multicolumn{2}{|c|}{ T } \\
\hline 1 & $\begin{array}{l}\text { Inadequate } \\
\text { Knowledge } \\
<50 \%\end{array}$ & 26 & 52 & 3 & 6 \\
\hline 2 & $\begin{array}{l}\text { Moderate } \\
\text { Knowledge } \\
51-75 \%\end{array}$ & 23 & 46 & 37 & 74 \\
\hline 3 & $\begin{array}{l}\text { Adequate } \\
\text { Knowledge } \\
>75 \%\end{array}$ & 1 & 2 & 10 & 20 \\
\hline
\end{tabular}

Table During the pre test 26(52\%) staff nurses had Inadequate Knowledge, $23(46 \%)$ of the staff nurses had Moderate Knowledge, and 1 (2\%) had Adequate Knowledge regarding legal aspects of forensic psychiatry. During the post test 3 $(6 \%)$ staff nurses had Inadequate Knowledge, $37(74 \%)$ of the staff nurses had Moderate Knowledge, and 10 (20\%) had Adequate Knowledge regarding legal aspects of forensic psychiatry.

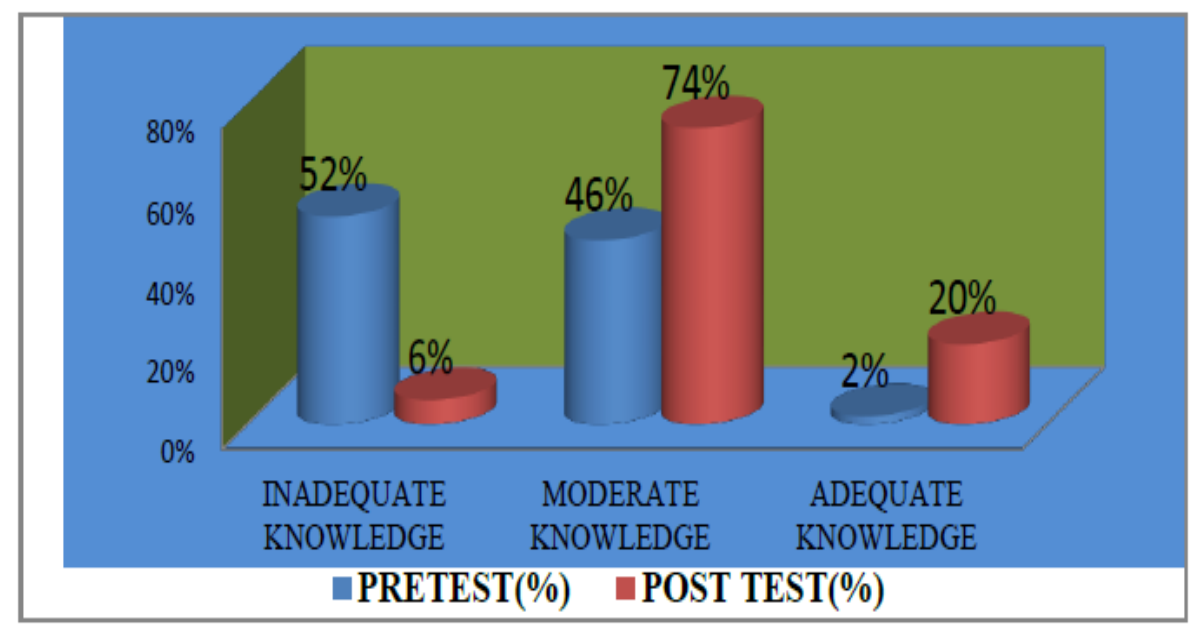

FIGURE 4.2.1: percentage distribution of samples according to pre test and post test knowledge level on legal aspects of forensic psychiatry among staff nurses. 
Punithavalli. P et.al. Effectiveness of structured teaching programme on knowledge regarding legal aspects of forensic psychiatry among staff nurses at selected hospital, Coimbatore.

Table 4.2.2: Distribution of statistical value of pretest and post test knowledge level regarding legal aspects of forensic psychiatry.

\begin{tabular}{|l|l|l|l|l|}
\hline S.NO & KNOWLEDGE LEVEL & MEAN & SD & 't value' \\
\hline 1 & Pre test & 15.22 & 2.54 & $\mathbf{1 1 . 6 1}^{*}$ \\
\hline 2 & Post test & 20.82 & 2.28 & \\
\hline
\end{tabular}

Table shows that the mean pre test score of knowledge was 15.22, SD (2.54) and post test mean score of knowledge was 20.82, SD (2.28) for 49 degree of freedom at 0.05 level of significance the calculated
' $t$ ' value was (11.61). Hence the calculated ' $t$ ' value is more than table value (1.960). It reveals that there was significance difference in the pre test and post test level of knowledge regarding legal aspects of forensic psychiatry. Therefore, the effectiveness of structured teaching programme on improving knowledge regarding legal aspects in forensic psychiatry is significantly proved.

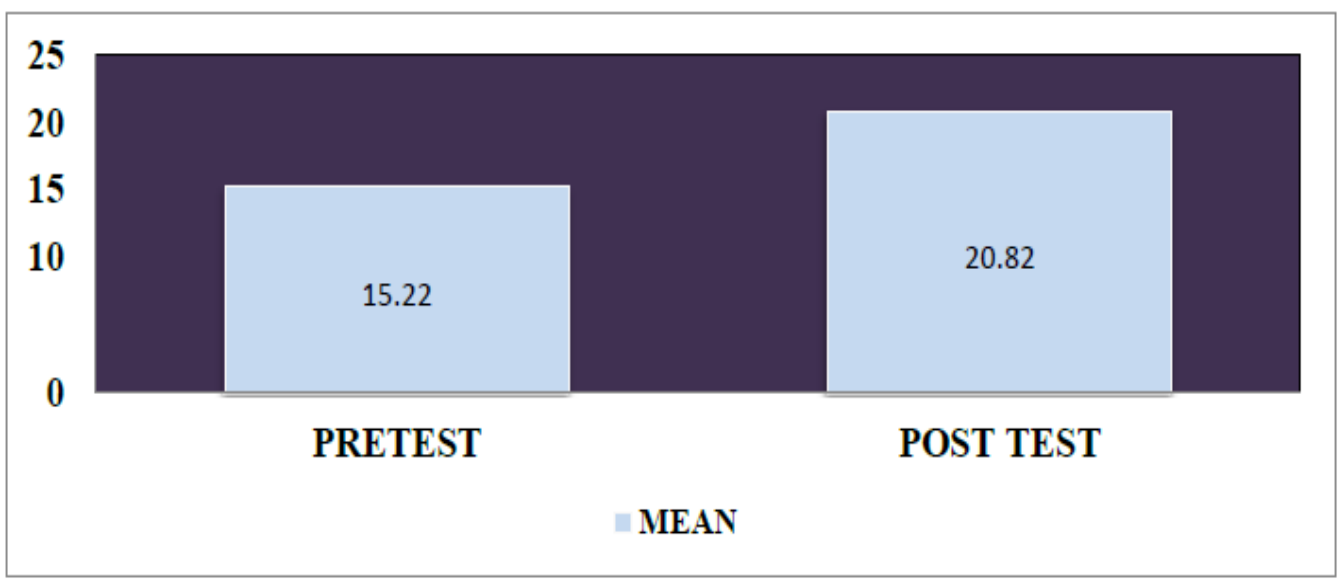

Association of Post Test Knowledge Regarding Legal Aspects In Forensic Psychiatry Among Staff Nurses With Selected Demographic Variables. $\quad(\mathbf{N}=50)$

\begin{tabular}{|c|c|c|c|c|}
\hline \multicolumn{2}{|c|}{ DEMOGRAPHIC VARIABLES } & ABOVE MEAN & BELOW MEAN & $\chi^{2}$ \\
\hline \multirow{4}{*}{ AGE } & a) $21-30 \mathrm{yrs}$ & 19 & 13 & \multirow{4}{*}{3.23} \\
\hline & b) $31-40 \mathrm{yrs}$ & 7 & 5 & \\
\hline & c) $41-50 \mathrm{yrs}$ & 1 & 2 & \\
\hline & d) Above 50 yrs & 3 & 0 & \\
\hline \multirow[b]{2}{*}{ GENDER } & a) Male & 8 & 8 & \multirow[t]{2}{*}{7.471} \\
\hline & b) Female & 20 & 14 & \\
\hline \multirow{4}{*}{ RELIGION } & a) Hindu & 21 & 13 & \multirow{4}{*}{17.66} \\
\hline & b) Muslim & 2 & 3 & \\
\hline & c) Christian & 7 & 4 & \\
\hline & d) Others & 0 & 0 & \\
\hline \multirow{3}{*}{$\begin{array}{l}\text { PROFESSIONAL } \\
\text { QUALIFICATION }\end{array}$} & a) Diploma in nursing & 20 & 18 & \multirow{3}{*}{6.107} \\
\hline & b) Post B.Sc. nursing & 7 & 1 & \\
\hline & c) B.Sc. nursing & 2 & 2 & \\
\hline \multirow{4}{*}{$\begin{array}{l}\text { MARITAL } \\
\text { STATUS }\end{array}$} & a) Married & 14 & 11 & \multirow{4}{*}{4.529} \\
\hline & b) un Married & 15 & 9 & \\
\hline & c) separated & 0 & 0 & \\
\hline & d) widow & 1 & 0 & \\
\hline \multirow{4}{*}{$\begin{array}{c}\text { CLINICAL } \\
\text { EXPERIENCE }\end{array}$} & a) $1-5$ years & 24 & 18 & \multirow{4}{*}{2.393} \\
\hline & b) 6- 10 years & 2 & 0 & \\
\hline & c) $11-15$ years & 1 & 2 & \\
\hline & d) Above 15 years & 3 & 0 & \\
\hline \multirow[t]{2}{*}{ MONTHLY INCOME (RS) } & a) $1-5$ years & 22 & 12 & \multirow[t]{2}{*}{2.756} \\
\hline & b) 6- 10 years & 7 & 8 & \\
\hline
\end{tabular}

DISCUSSION

The First Objective of the Study to Assess the Level Knowledge Regarding Legal Aspects In Forensic Psychiatry Among Staff Nurses
Structured questionnaire method was used to assess the pretest score of knowledge regarding legal aspects in forensic psychiatry among staff nurses. During pretest most of the staff nurses had 
$26(52 \%)$ demonstrated inadequate knowledge, some of the staff nurses had moderate knowledge $23(46 \%)$ and 1(2\%) had adequate knowledge.

\section{The Second Objective of the Study to} administer structured teaching programme regarding the legal aspects in forensic psychiatry among staff nurses.

The structured teaching programme was given to the staff nurses of PSG Hospital and Naveen Hospital, Coimbatore. The teaching was given through power point presentation it included the definition, law (criminal and civil law), mental health act and rights of mentally ill patients.

The Third Objective of the Study to Evaluate the Effectiveness of Structured Teaching Programme on Level of Knowledge Regarding Legal Aspects in Forensic Psychiatry among Staff Nurses.

The obtained ' $t$ ' value for the knowledge was 11.61 at 49 degree freedom significant at 0.05 level. The mean score of post test knowledge was higher than pre test knowledge. Hence the knowledge regarding legal aspects of forensic psychiatry among staff nurses by providing structured teaching programme is improved.

\section{The Fourth Objective of the Study to Find out the Association Between Selected Demographic Variables with the Post Test Knowledge Score of Staff Nurses.}

The demographic variables such as age, gender, religion, professional qualification, marital status, clinical experience, monthly income, previous source of knowledge, by using $\mathrm{x} 2$ test. It reveals that there is a significant association between post test knowledge with age, professional qualification, marital status, clinical experience, monthly income, previous source of knowledge.

\section{CONCLUSION}

The researcher concluded that the structured teaching programme increased the knowledge level of legal aspects of Forensic psychiatry among staff nurses in selected hospitals in Coimbatore.
Acknowledgement: None

Conflict of Interest: None

Source of Funding: None

Ethical Approval: Approved

\section{REFERENCES}

1. Basavanthappa B.T (2003). Nursing research. (1st edition). New Delhi :Jaypee Publishers.

2. Basavanthappa B.T (2009). Nursing Theories. (1st Edition). New Delhi: Jaypeebrothers medical publications

3. BhaskarRao (2000). Methods of bio statistics (2nd edition). Hyderaba: Paras publishers.

4. Clement. I (2005). Basic concept of psychiatric nursing. (1st edition). New Delhi: A.P Jain and co publication.

5. Denise F.P and Cheryl T.B (2006). Nursing Research. (2nd Edition). Newyork: Lippincott company.

6. Dr. Dixit J.V and Suryavanshi L.B (1996). Principles and practice of Bio-statistics. (1st Edition). Jabalpur: M/S BanarsidasBhanot Publishers.

7. Edward. F and Zigler (1985). Child Developments and social issue. 1st edition). Texington: D.C. Health and company publishers.

8. Elizabath.B. Hurlock(2003). Developmental Psychology- A life span approach (5th Edition). New Delhi: Tata MC Graw publishing company.

9. Fortinash K.M and HolodayWorrt P.A (2000). Psychiatric mental health nursing. (2nd edition). Newyork: Mosby publications.

10. Gail. W.Stuart and lasraris. M.T (2001). Principles and practice of Psychiatric Nursing. ( $7^{\text {th }}$ Edition). Newyork: Mosby Publishers.

11. Goel B.S (1986). Psycho-Analysis and Meditation. (1st Edition). New Delhi: Paragon Enterprises. Sons Educational Publishers.

12. Gurumani N (2004). An Introduction of Bio-statistics. (1st edition). India: MSP publication.

13. Johnson (1986). Psychiatric mental health nursing adaptation and growth. (2nd 
edition). Philadelphia: J.B. Lippincott Company.

14. Kaplan H.P and Sadok, B.J (1982). Modern Synopsis of comprehensive textbook of psychiatry. (3rd edition). Baltimore: Williams and Williams publication.

15. Kothari C.R (2001). Research methodology. (2nd edition). New Delhi: Woshva Prakam publishers.

16. Kothari C.R (2005). Research methodology and Techniques. (2nd edition). New Delhi: International private (ltd).

17. Lanca A.T (1995). Principles and Practice of Nursing Research. (3rd edition). Indore: Mosby \& Co Publishers.

18. Laraia and Stuart (1998). Principles and practice of psychiatric nursing. (6th edition). Philadelphia: Mosby Company.

19. Lonsri Wongchai (1998). Mental Health and psychiatric Nursing. (1stedtion). Chiang. Main University press.

20. Louise Rebraca Shives (2009). Psychiatric mental health nursing. (1st edition). Philadelphia: Wolter Klumber and Lippincott publication.

21. Mahajan B.K (1997). Methods in Biostatistics. (6th edition). New Delhi :Jaypee Publications.

\section{JORUNALS}

22. Suresh KS. A study to assess the awareness regarding human rights of mentally ill among staff nurses. 2009. Available on www.rguhs. ac.in>onlinecdc >upload.

23. Kunjumon Betty P. The knowledge and practice of trained nurses in protecting patient rights and factors interfering them. Nurs J India 2006; XC 2(4):90-91.

24. Ozdemir Haken M. Midwives and nurses awareness of patient's rights. Midwifery 2009;25(6):756-765.

DOI: 10.1016/j.midw.2008.01.010.

25. Barnabas S. Study to assess knowledge of legal responsibilities in patient care among graduates. Nurse J India 2004;95(4):90-91.
26. Hariharan S, Jonnalagadda R, Walrond E, et al. Knowledge, attitudes and practice of healthcare ethics and law among doctors and nurses in Barbados. BMC Med Ethics 2006;7(1):E7. DOI: 10.1186/1472-6939-7-7

27. Cutcliffe, JR. Whose life is it anyway? An exploration of five contemporary ethical issues that pertain to the psychiatric nursing care of the person who is suicidal. International Journal of Mental Health Nursing 2008; August; 17(4):236- 245.

28. Hariharan S, Jonnalagadda R, Walrond E, Moseley H. Knowledge, attitudes and practice of healthcare ethics and law among doctors and nurses in Barbados. BMC Medical Ethics 2006; June; 7(7). Available from: URL: http:// www.biomedcentral.com/1472-6939/7/7

29. Forchuk C.€ Ethical problems encountered by mental health nurses. Issues in Mental Health Nursing 1991;12(4):375-83.

30. Barnabas S. A study to assess knowledge of legal responsibility in patient care among nursing graduates. The Nursing Journal of India 2004; April; XCV(4):90-91.

31. Times of India, Dysfunctional Mental Hospitals, Jan 7, 2007 ,Views€ 4098€ , Tags:€ Indian lunacy act 1912,€ mental health act, 1982€ national human rights commission.

32. McCarthy RL. Legal issues and patient privacy and confidentiality. International journal of nursing Studies. 2001; Dec; 56(12): 1580-4.

How to cite this article: Punithavalli. P, Abirami, Jebaseeli Gladies et.al. Effectiveness of structured teaching programme on knowledge regarding legal aspects of forensic psychiatry among staff nurses at selected hospital, Coimbatore. Galore International Journal of Applied Sciences \& Humanities. 2022; 6(1): 1-6. DOI: https://doi.org/10.52403/gijash.20220101 